\title{
Establishment of Range Grasses on Various Seedbeds at Creosotebush [Larrea tridentata] Sites in Arizona, U.S.A., and Chihuahua, Mexico
}

\author{
JERRY R. COX, MARTHA H. MARTIN-R., FERNANDO A. IBARRA-F., AND HOWARD L. MORTON
}

\begin{abstract}
Perennial grasses were seeded by drilling or broadcasting on 4 mechanical and 3 herbicidal weed control and/or seedbed preparation treatments at 4 semidesert grassland sites invaded by creosotebush (Larrea tridentata) in the Chihuahuan and Sonoran Deserts. The cultivars 'Cochise' Atherstone lovegrass (Eragrostis lehmanniana $\times$ Eragrostis trichophera) and 'Catalina' Boer lovegrass (Eragrostis curvula var. conferta) lovegrasses were initially established and persisted in 6 of the 8 plantings on disk plowed and disk plowed plus contour furrowed seedbeds. These grasses were established and persisted in 2 of the 5 plantings made in creosotebush stands treated with tebuthiuron [ $N$-(5-(1,1-dimethylethyl)1,3,4-thiadizol-2-yl)- $N$ - $N^{\prime}$-dimethylurea] at $0.5,1.0$, and $1.5 \mathrm{~kg}$ a.i/ha rates. Grasses established initially on two-way railed and land imprinted areas usually died within 3 or 4 years.
\end{abstract}

Creosotebush (Larrea tridentata), a woody perennial shrub, has invaded the semidesert grasslands within the Chihuahuan and Sonoran Deserts of North America (Humphrey 1958, Buffington and Herbel 1965, Hastings and Turner 1965). As creosotebush densities increase, perennial grass densities decline (Anderson et al. 1957). Therefore, it is desirable to replace creosotebush with perennial grasses to reduce soil erosion, increase infiltration, and provide forage for domestic livestock.

\footnotetext{
Jerry Cox and Howard Morton are range scientist and supervisory plant physiologist, respectively; USDA, Agricultural Research Service, Aridland Watershed Management Research Unit, 2000 E. Allen Road, Tucson, Ariz. 85719; Martha Martin-R. and Fernando Ibarra-F. are head of the Department of Range Management and Technical Director, respectively, CIPES, Periferico OTS S/N, Conjunto UGRS, Postal 1754, Hermosillo, Sonora, Mexico. When this study was initiated Martha Martin-R. and Fernando Ibarra-F. were graduate students, School of Renewable Natural Resources, University of Arizona, Tucson.

Appreciation is extended to Consejo Nacional de Ciencia y Tecnologia (Mexico) for financial support; Elanco Products Company for the herbicide and fencing materials at the Mexican sites; Drs. Luis Carlos Fierro, Thomas N. Johnsen, Jr., and Gilbert L. Jordan for technical assistance; personnel at Rancho Experimental La Campana, Chihuahua, Mexico, and Aridland Watershed Management Research Unit, Tucson, Ariz., for setting up plots, applying treatments, and collecting data; and ranchers Eloy Morales, Sergio Mendoza, and Gilberto Valdez for permission to use their land and housing facilities. The Rocky Mountain Forest and Range Experiment Station gave permission to use land at the Santa Rita Experimental Range.

Lovegrass seeds were provided by U.S. Dep. Agr., Soil Conservation Service, Plant Materials Center, Tucson, Arizona. Kleingrass and sideoats grama seeds were provided by Rancho Experimental La Campana. Buffelgrass seeds were provided by Centro de Investigacions Pecuarias del Estado Sonora, Carbo, Sonora, Mexico. Manuscript accepted 5 May 1986.
}

For the past 90 years creosotebush management has consisted of mechanical tillage to reduce creosotebush competition and prepare a seedbed for seeding perennial grasses (Cox et al. 1982). Mechanical tillage disturbs surface soils and aids in rainwater infiltration (Jordan 1981), but seedings at creosotebush site were seldom successful and the treated area is usually reinvaded by creosotebush or annual forbs and grasses (Cox et al. 1984a).

Pelleted tebuthiuron [ $N$-(5-(1,1-dimethylethyl)-1,3,4-thiadiazol2 -yl)- $N$ - $N^{\prime \prime}$-dimethylurea] effectively controls creosotebush (Jacoby et al. 1982) and perennial grasses can be established if grass seeds and pellets are applied at the same time (Baur et al. 1977). Grass seedlings, however, may not survive if pellets are applied after seeds germinate because seedling roots encounter the herbicide as it moves through the upper soil profile (Baur 1979).

The semidesert grasslands of the southwestern U.S.A. and northern Mexico are of great importance to the livestock industry, but the chances of reestablishing forage grasses are low because of erratic precipitation in summer. Therefore, it is important to address the effects of precipitation on plant establishment, persistence, and forage production.

More than 300 forb, grass, and shrub species have been sown at 400 locations in the southwestern U.S.A. and northern Mexico during the past 90 years (Cox et al. 1982). A successful seeding was more likely to occur if seed of the following species were sown prior to the summer rains: (1) 'A-68' Lehmann lovegrass (Eragrostis lehmanniana), (2) 'A-84' and (3) 'Catalina' Boer lovegrass (E. curvula var. conferta), (4) 'Cochise' Atherstone lovegrass ( $E$. lehmanniana $\times$ E. trichophera), (5) 'S-75' Kleingrass (Panicum coloratum), (6) 'Premier'sideoats grama (Bouteloua curtipendula), and (7) 'common' buffelgrass (Cenchrus ciliaris).

Researchers have evaluated either the relationships between mechanical seedbed preparation and grass establishment or chemical seedbed preparations and grass establishment, but have not attempted to directly compare both seedbed preparations. The purpose of this study was to compare establishment potential and persistence of 7 perennial grasses sown in mechanically and chemically prepared seedbeds.

\section{Methods}

The study was conducted at the Santa Rita Experimental Range 
Table 1. Site characteristics and soll classification for seeding study sites at Santa Rita Experimental Range (SRER) Arizona, U.S.A. and at Ranchos La Reforma, Los Pozos and EI Toro, in Chihuahua, Mexico.

\begin{tabular}{|c|c|c|c|c|c|c|c|}
\hline \multirow[b]{2}{*}{ Sites } & \multirow[b]{2}{*}{ Elevation } & \multicolumn{2}{|c|}{ Mean ${ }^{1}$ precipitation } & \multicolumn{2}{|c|}{$\begin{array}{c}\text { Mean } \\
\text { extreme temperature }\end{array}$} & \multicolumn{2}{|r|}{ Soils } \\
\hline & & Summer & Winter & Max. & Min. & Series & Classification $^{2}$ \\
\hline & $-\mathbf{m}--$ & - & & 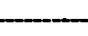 & - & & \\
\hline SRER & 970 & 190 & 130 & 44 & 4 & Anthony & loamy, thermic, Typic Torrifluvent \\
\hline La Reforma & 1,500 & 240 & 160 & 37 & -16 & Kimbrough & $\begin{array}{l}\text { loamy, mixed, thermic, shallow Petro- } \\
\text { calcic, Calciustoll }\end{array}$ \\
\hline Los Pozos & 1,400 & 150 & 105 & 40 & -10 & Jerag & $\begin{array}{l}\text { loamy, mixed, thermic, shallow, } \\
\text { Petrocalcic Ustollic Paleargid }\end{array}$ \\
\hline El Toro & 1,380 & 160 & 110 & 42 & -13 & Algerita & $\begin{array}{l}\text { loamy, mixed, thermic, coarse, } \\
\text { Ustollic Typic Calciorthid }\end{array}$ \\
\hline
\end{tabular}

'Means are from COTECOCA. (1978), Green and Martin (1967).

2Soil classification is from Soil Survey Staff (1975).

(SRER), $40 \mathrm{~km}$ south of Tucson, Ariz., in the Sonoran Desert; Rancho La Reforma, $60 \mathrm{~km}$ east of Parral, Chihuahua; Rancho Los Pozos, $20 \mathrm{~km}$ northeast of Aldama, Chihuahua; and Rancho El Toro, $100 \mathrm{~km}$ east of Villa Ahumada, Chihuahua; all are within the Chihuahuan Desert.

Elevation is least at SRER, intermediate at Los Pozos and El Toro, and greatest at La Reforma (Table 1). Precipitation distribution is approximately $60 \%$ in summer and $40 \%$ in winter at all sites. Freezing temperatures infrequently occur in winter at SRER, but are common in winter and spring at La Reforma, Los Pozos, and El Toro. Slope inclination varies from 2 to $16 \%$ at La Reforma, and from 0 to $5 \%$ at the other 3 sites. Surface soil textures at the 4 sites are sandy loam and a caliche hard pan is present from 5 to $100 \mathrm{~cm}$.

Creosotebush is the predominant shrub species except at La Reforma where it shares codominance with whitethorn (Acacia constricta) and shrubby senna (Cassia wislizenii). Desert zinnia (Zinnia pumila) and mariola (Parthenium incanum) are present at SRER. Whitethorn, mesquite (Prosopis spp.), and tarbush (Flourensia cernua) are present at Los Pozos and El Toro.

Each study site was fenced to exclude livestock in summer 1981 . The following 8 seedbed preparations were applied on 50 by $100-\mathrm{m}$ plots: (1) untreated check, (2) two-way railing, (3) disk plowing, (4) disk plowing plus contour furrowing, (5) land imprinting, and tebuthiuron pellets containing $20 \%$ active ingredient (a.i.) hand applied at rates of (6) 0.5 , (7) 1.0 , and (8) $1.5 \mathrm{~kg} / \mathrm{ha}$.

Three 2.65-m lengths of railroad steel were bolted together to form a triangle and weighted with rocks (approximately $770 \mathrm{~kg}$ ).
The rail was pulled over the plot twice in opposite directions. A standard 3-bottom disk plow on a 3-point hitch weighing $500 \mathrm{~kg}$ was used at the Mexican sites, and a pull-type 3-bottom disk plow weighing $2,000 \mathrm{~kg}$ at SRER. Both disk plows had $64-\mathrm{cm}$ disks which penetrated soils to $30 \mathrm{~cm}$. A border disk constructed contour furrows at $10-\mathrm{m}$ intervals.

The land imprinter, fabricated from $1.27-\mathrm{cm}$ steel plate, consisted of 2 nondirectional geometric forms ( $\mathrm{V}$-pitter and pit-digger) welded on separate 1 by $1 \mathrm{~m}$ cylinder capsules. Capsules were linked on an axle shaft. Capsules were filled with water, and iron boxes located at the front and rear were filled with rocks to aid in soil penetration (Dixon and Simanton 1980). Total weight was approximately 4 metric tons.

The tebuthiuron pellets were distributed on 20 swaths, spaced 5 $\mathrm{m}$ apart along the $100-\mathrm{m}$ plot length, and on 10 swaths, spaced $5 \mathrm{~m}$ apart along the $50-\mathrm{m}$ plot width. The clay pellets were $3.2 \mathrm{~mm}$ in diameter and approximately $4.8 \mathrm{~mm}$ in length.

Mechanical seedbeds were prepared between 15 June and 17 July in 1981, and between 26 May and 27 June in 1982. Land imprinted seedbeds were prepared at all sites only in 1982 . The herbicide was applied in May both years.

Seeds of 'A-68' Lehmann lovegrass, 'A-84' and 'Catalina' Boer lovegrass, 'Cochise' Atherstone lovegrass, 'S-75' Kleingrass, 'Premier' sideoats grama and 'common' buffelgrass, hereafter referred to as species, were either drilled across all seedbeds or hand broadcast on mechanically prepared seedbeds. Buffelgrass was seeded only at Los Pozos in 1981, but at all sites in 1982.

Table 2. Density and forage production of range grasses averaged over 7 or 8 seedbed preparations following drill seeding in summer 1981 and 1982 at Santa Rita Experimental Range, Arizona, U.S.A.

\begin{tabular}{|c|c|c|c|c|c|c|c|c|}
\hline \multirow{2}{*}{\multicolumn{2}{|c|}{ Year }} & \multicolumn{7}{|c|}{ Grass } \\
\hline & & \multicolumn{4}{|c|}{ Lovegrasses } & \multirow[b]{2}{*}{ Kleingrass } & \multirow[b]{2}{*}{ Sideoats grama } & \multirow[b]{2}{*}{ Buffelgrass } \\
\hline Seeded & Evaluated ' & A-68 & Cochise & A-84 & Catalina & & & \\
\hline 1981 & $\begin{array}{l}1981 \\
1982 \\
1983 \\
1984\end{array}$ & $\begin{array}{l}0^{c} \\
1^{b} \\
1^{b} \\
1^{b}\end{array}$ & $\begin{array}{l}1^{b} \\
2^{a} \\
3^{a} \\
6^{a}\end{array}$ & $\begin{array}{l}1^{b} \\
1^{b} \\
1^{b} \\
1^{b}\end{array}$ & $\begin{array}{c}\text { ensity (Pl } \\
1^{\mathrm{b}} \\
2^{\mathrm{a}} \\
4^{\mathrm{a}} \\
6^{\mathrm{a}}\end{array}$ & $\begin{array}{l}1^{b} \\
2^{a} \\
1^{b} \\
1^{b}\end{array}$ & $\begin{array}{l}3^{a} \\
2^{a} \\
1^{b} \\
1^{b}\end{array}$ & \\
\hline 1982 & $\begin{array}{l}1982 \\
1983 \\
1984\end{array}$ & $\begin{array}{l}4^{c} \\
1^{b} \\
1^{c}\end{array}$ & $\begin{array}{r}11^{a} \\
1^{b} \\
7^{a}\end{array}$ & $\begin{array}{l}2^{c} \\
1^{b} \\
1^{c}\end{array}$ & $\begin{array}{l}7^{b} \\
3^{a} \\
4^{b}\end{array}$ & $\begin{array}{l}7^{b} \\
1^{b} \\
1^{c}\end{array}$ & $\begin{array}{l}3^{c} \\
1^{b} \\
1^{c}\end{array}$ & $\begin{array}{l}8^{\mathrm{ab}} \\
2^{\mathrm{ab}} \\
1^{\mathrm{c}}\end{array}$ \\
\hline $\begin{array}{l}1981 \\
1982\end{array}$ & $\begin{array}{l}1983 \\
1984 \\
1983 \\
1984\end{array}$ & $\begin{array}{r}1^{d} \\
15^{c} \\
47^{d} \\
94^{d}\end{array}$ & $\begin{array}{l}212^{a} \\
351^{a} \\
217^{b} \\
417^{a}\end{array}$ & $\begin{array}{r}80^{\mathrm{c}} \\
37^{\mathrm{c}} \\
129^{\mathrm{c}} \\
81^{\mathrm{d}}\end{array}$ & $\begin{array}{c}178^{\mathrm{a}} \\
164^{\mathrm{b}} \\
236^{\mathrm{ab}} \\
223^{\mathrm{b}}\end{array}$ & $\begin{array}{c}\left(\mathrm{g} / \mathrm{m}^{2}\right) \\
59^{\mathrm{c}} \\
109^{\mathrm{bc}} \\
110^{\mathrm{c}} \\
134^{\mathrm{c}}\end{array}$ & $\begin{array}{l}142^{\mathrm{b}} \\
106^{\mathrm{bc}} \\
151^{\mathrm{bc}} \\
113^{\mathrm{cd}}\end{array}$ & $\begin{array}{l}283^{\circ} \\
184^{b c}\end{array}$ \\
\hline
\end{tabular}

IMeans in rows followed by the same letter are not significantly different $(\alpha=0.05)$ by Duncan's multiple range test. 


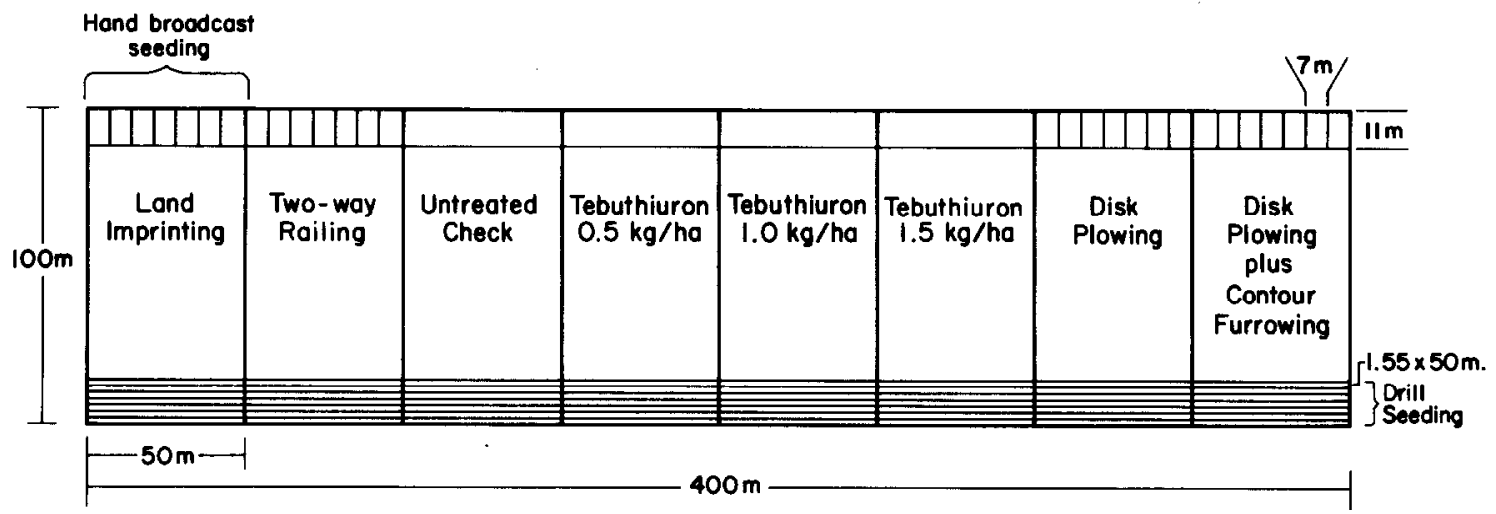

Fig. 1. The relationship between drill seeding and hand broadcast seeding subplots within an 8-plot group of chemical and mechanical seedbeds.

With the exception of buffelgrass and sideoats grama, seed were sown with a precalibrated half-size rangeland drill in 5 rows spaced $31 \mathrm{~cm}$ apart at SRER in 1981 and at all sites in 1982. Planting depths ranged from 0 to $2.5 \mathrm{~cm}$ because of rough terrain and drill inaccuracy. Buffelgrass and sideoats grama glumes had not been removed and seed would not pass uniformly through the drill. These species were hand broadcast directly into furrows after the drill passed.

At the Mexican sites in 1981 and at all sites in 1982, seed were hand broadcast immediately after two-way railing, disk plowing, and disk plowing plus contour furrowing. When a plot was to be land imprinted in 1982, seed were either hand broadcast on the soil surface or drill coulters were raised and seed deposited directly on soil. After seed had been sown, the plot was imprinted.

Subplot size for each species was 1.55 by $50 \mathrm{~m}\left(77.5 \mathrm{~m}^{2}\right)$ in drill seeded areas and 7 by $11 \mathrm{~m}\left(77 \mathrm{~m}^{2}\right)$ in hand seeded areas. Lovegrass seeds were sown at pure live seed (PLS) rates of $1.5 \mathrm{~kg} / \mathrm{ha}$, Kleingrass at $2.0 \mathrm{~kg} / \mathrm{ha}$, buffelgrass at $3.0 \mathrm{~kg} / \mathrm{ha}$, and sideoats grama at 5 kg/ ha (Huss and Aguirre 1974, Jordan 1981). Seed were planted by hand and drill at the same PLS rates on mechanically prepared seedbeds to allow a comparison of the 2 planting techniques.

\section{Data Collection}

Twenty 30 by $60-\mathrm{cm}$ quadrats were randomly selected within each seeded subplot. The 2 exterior drill rows and the outer $1 \mathrm{~m}$ of the hand broadcast subplots were omitted. We counted the numbers of seeded species in all quadrats, and clipped plants at the soil surface in 5 randomly selected quadrats. Forage was estimated in the remaining 15 quadrats (Pechanec and Pickford 1937) and clipped areas were omitted in future sampling dates. Clipped samples were dried in a forced-draft oven at $40^{\circ} \mathrm{C}$ for $48 \mathrm{~h}$, and dry weights from unclipped field samples estimated using regression techniques (Campbell and Cassady 1949).

We measured plant density annually in fall 1981-1984 on subplots sown in 1981, and in fall 1982-1984 on subplots sown in 1982. We measured forage production in fall 1983 and 1984 on subplots sown in 1981 and 1982. Rainfall was measured on site.

\section{Experimental Design}

Each study area was divided into 2 parts; 1 for treatment in 1981 and 1 for treatment in 1982. Each part was subdivided into 24 plots, 50 by $100 \mathrm{~m}$. The experimental design was a randomized block with 3 replications.

Six grasses were drill seeded across 7 seedbeds in 1981 at SRER, and 7 grasses were drill seeded across 8 seedbeds in 1982 at all sites. Space and lack of equipment maneuverability limited a complete randomization of species; therefore, species were randomized within each block (Fig. 1). Because seedbed preparations and grasses are randomized at different levels, the design is a stripblock (Federer 1967). There is no main plot in the design and we tested seed bed preparations, grasses and the seedbed preparation by grasses interaction with the same error term.

Six grasses were hand broadcast on 3 mechanically prepared seedbeds at 2 sites, and 7 grasses at 1 site in 1981; and 7 grasses hand broadcast on 4 mechanically prepared seedbeds at 4 sites in 1982 . Seedbeds and grasses were completely randomized and the design was a split-plot, with seedbeds as main plots and grasses as subplots (Fig. 1).

Density and forage production data from the 20 quadrats within each subplot were averaged and the mean considered a replication. The amount and distribution of summer rainfall was highly variable among sites in the same year, and among years at the same site.

Table 3. Mean density and forage production of 6 or 7 grasses on 8 seedbed preparations following drill seeding in summer 1981 and 1982 at Santa Rita Experimental Range, Arizona, U.S.A.

\begin{tabular}{|c|c|c|c|c|c|c|c|c|c|}
\hline \multicolumn{2}{|c|}{ Year } & \multirow[b]{3}{*}{ Control } & \multicolumn{4}{|c|}{ Mechanical Seedbeds } & \multirow{2}{*}{\multicolumn{3}{|c|}{$\begin{array}{c}\text { Chemical Seedbeds } \\
\text { Active Rate Tebuthiuron }\end{array}$}} \\
\hline \multirow[b]{2}{*}{ Seeded } & \multirow[b]{2}{*}{ Evaluated } & & \multirow{2}{*}{$\begin{array}{l}\text { Two-way } \\
\text { Railing }\end{array}$} & \multirow{2}{*}{$\begin{array}{c}\text { Disk } \\
\text { Plowing }\end{array}$} & \multirow{2}{*}{$\begin{array}{l}\text { Disk Plowing plus } \\
\text { Contour Furrowing }\end{array}$} & \multirow{2}{*}{$\begin{array}{c}\text { Land } \\
\text { Imprinting }\end{array}$} & & & \\
\hline & & & & & & & 0.5 & 1.0 & 1.5 \\
\hline 1981 & $\begin{array}{l}1981 \\
1982 \\
1983 \\
1984\end{array}$ & $\begin{array}{l}0^{c} \\
0^{b} \\
1^{b} \\
1^{b}\end{array}$ & $\begin{array}{l}2^{b} \\
1^{a} \\
2^{a b} \\
1^{b}\end{array}$ & $\begin{array}{c}2^{b} \\
1^{a} \\
4^{a} \\
1^{b}\end{array}$ & $\begin{array}{c}4^{\mathrm{a}} \\
2^{\mathrm{a}} \\
2^{\mathrm{ab}} \\
1^{\mathrm{b}}\end{array}$ & $\left.1^{2}\right)-$ & $\begin{array}{l}0^{c} \\
2^{a} \\
2^{a b} \\
3^{a}\end{array}$ & $\begin{array}{l}0^{c} \\
2^{a} \\
2^{a b} \\
4^{a}\end{array}$ & $\begin{array}{l}0^{c} \\
1^{a} \\
2^{a b} \\
4^{a}\end{array}$ \\
\hline 1982 & $\begin{array}{l}1982 \\
1983 \\
1984\end{array}$ & $\begin{array}{l}2^{c} \\
1^{c} \\
1^{b c}\end{array}$ & $\begin{array}{l}8^{b} \\
2^{b} \\
2^{b}\end{array}$ & $\begin{array}{r}12^{a} \\
3^{a b} \\
3^{a b}\end{array}$ & $\begin{array}{r}14^{a} \\
4^{a} \\
4^{n}\end{array}$ & $\begin{array}{l}4^{c} \\
1^{c} \\
1^{b c}\end{array}$ & $\begin{array}{l}4^{c} \\
1^{c} \\
2^{b}\end{array}$ & $\begin{array}{l}3^{c} \\
1^{c} \\
3^{a b}\end{array}$ & $\begin{array}{l}3^{c} \\
1^{c} \\
4^{a}\end{array}$ \\
\hline $\begin{array}{l}1981 \\
1982\end{array}$ & $\begin{array}{l}1983 \\
1984 \\
1983 \\
1984\end{array}$ & $\begin{array}{c}4^{d} \\
42^{c} \\
10^{d} \\
80^{c}\end{array}$ & $\begin{array}{l}136^{\mathrm{b}} \\
118^{\mathrm{bc}} \\
202^{\mathrm{b}} \\
158^{\mathrm{b}}\end{array}$ & $\begin{array}{c}226^{a} \\
99^{b c} \\
385^{a} \\
215^{\star}\end{array}$ & $\begin{array}{l}\text { orage Productio } \\
291^{\mathrm{a}} \\
142^{\mathrm{b}} \\
466^{\mathrm{a}} \\
290^{\mathrm{a}}\end{array}$ & $\begin{array}{c}12^{d} \\
153^{b}\end{array}$ & $\begin{array}{r}51^{\mathrm{c}} \\
148^{\mathrm{b}} \\
137^{\mathrm{c}} \\
99^{\mathrm{c}}\end{array}$ & $\begin{array}{r}29^{\mathrm{c}} \\
203^{*} \\
81^{\mathrm{c}} \\
224^{\mathrm{a}}\end{array}$ & $\begin{array}{r}18^{\mathrm{c}} \\
232^{\mathrm{a}} \\
57^{\mathrm{cd}} \\
206^{\mathrm{ab}}\end{array}$ \\
\hline
\end{tabular}

'Means in rows followed by the same letter are not significantly different ( $\alpha=0.05)$ by Duncan's multiple range test. 
Table 4. Density and forage production of range grasses averaged over 3 mechanical seedbed preparations following hand broadcasting in summer 1981 at 3 sites in Chihuahu, Mexico.

\begin{tabular}{|c|c|c|c|c|c|c|c|c|}
\hline & & \multicolumn{7}{|c|}{ Grass } \\
\hline \multicolumn{2}{|c|}{ Year } & \multicolumn{4}{|c|}{ Lovegrasses } & \multirow[b]{2}{*}{ Kleingrass } & \multirow[b]{2}{*}{ Sideoats grama } & \multirow[b]{2}{*}{ Buffelgrass } \\
\hline Site & Evaluated' & A-68 & Cochise & A-84 & Catalina & & & \\
\hline \multirow{5}{*}{ La Reforma } & & & & & ensity ( $P$ ) & $\left.\mathbf{1}^{2}\right)-\cdots$ & & \\
\hline & 1981 & $0^{d}$ & $9^{c}$ & $0^{d}$ & $8^{c}$ & $51^{2}$ & $30^{\mathrm{b}}$ & \\
\hline & 1982 & $0^{\mathbf{c}}$ & $2^{b}$ & $0^{\mathfrak{c}}$ & $1^{b}$ & $11^{a}$ & $9^{n}$ & \\
\hline & 1983 & $0^{b}$ & 1 & $0^{b}$ & $1 *$ & $1^{2}$ & $1^{n}$ & \\
\hline & 1984 & $0^{b}$ & $1^{4}$ & $0^{b}$ & $0^{\mathrm{b}}$ & $1^{2}$ & 1 & \\
\hline \multirow[t]{4}{*}{ Los Pozos } & $1981^{2}$ & $2^{b}$ & $7^{\mathrm{ab}}$ & $0^{c}$ & $5^{\mathrm{ab}}$ & $9^{a}$ & $4^{b}$ & $10^{*}$ \\
\hline & $1982^{2}$ & $2^{b}$ & $4^{b}$ & $0^{\mathrm{c}}$ & $5^{b}$ & $10^{n}$ & $2^{b}$ & $11^{\mathrm{a}}$ \\
\hline & $1983^{2}$ & $2^{\mathrm{h}}$ & $2^{b}$ & $0^{c}$ & $2^{b}$ & $3^{b}$ & $2^{\mathrm{b}}$ & $6^{n}$ \\
\hline & $1984^{2}$ & $1^{b}$ & $2^{n}$ & $0^{c}$ & $2^{\mathrm{a}}$ & $1^{b}$ & $1^{b}$ & $2^{2}$ \\
\hline \multirow[t]{4}{*}{ El Toro } & 1981 & $2^{c}$ & $32^{a}$ & $2^{b}$ & $39^{a}$ & $36^{\mathrm{a}}$ & $44^{*}$ & \\
\hline & 1982 & $4^{c}$ & $14^{b}$ & $2^{c}$ & $16^{\mathrm{b}}$ & $21^{\mathrm{ab}}$ & $23^{n}$ & \\
\hline & 1983 & $2^{e}$ & $10^{\mathrm{nb}}$ & $2^{c}$ & $9^{b}$ & $15^{\mathrm{a}}$ & $12^{\mathrm{ab}}$ & \\
\hline & 1984 & $2^{b}$ & $4^{a}$ & $1^{b}$ & $4^{2}$ & $5^{n}$ & $5^{n}$ & \\
\hline \multirow[t]{2}{*}{ La Reforma } & 1983 & $0^{b}$ & $1^{*}$ & $0^{b}$ & rage Prod & $\left(g / m^{2}\right)-$ & $1^{\star}$ & \\
\hline & 1984 & $0^{c}$ & $7^{b}$ & $0^{\mathrm{c}}$ & $0^{c}$ & $38^{n}$ & $18^{b}$ & \\
\hline \multirow[t]{2}{*}{ Los Pozos } & $1983^{2}$ & $6^{b}$ & $11^{\mathrm{b}}$ & $0^{c}$ & $14^{\mathrm{b}}$ & $14^{\mathrm{b}}$ & $6^{b}$ & $66^{n}$ \\
\hline & $1984^{2}$ & $12^{b}$ & $23^{b}$ & $0^{c}$ & $5^{b}$ & $8^{b}$ & $8^{b}$ & $43^{\mathrm{a}}$ \\
\hline \multirow[t]{2}{*}{ El Toro } & 1983 & $19^{\mathrm{bc}}$ & $59^{n}$ & $10^{\mathrm{c}}$ & $25^{\mathrm{b}}$ & $28^{b}$ & $21^{\mathrm{b}}$ & \\
\hline & 1984 & $35^{b}$ & $87^{a}$ & $9^{c}$ & $36^{\mathrm{b}}$ & $33^{b}$ & $24^{\mathrm{b}}$ & \\
\hline
\end{tabular}

'Means in rows followed by the same letter are not significantly different $(\alpha=0.05)$ by Duncan's multiple range test.

${ }^{2}$ Grazed by cattle.

Because of this, statistical comparisons are site specific for seedbed preparations and grasses within a year. Data were subjected to analyses of variance to determine differences $(\alpha=0.05)$ among seedbed preparations, grasses, and the seedbed preparations by grasses interaction. Interactions were not significant; therefore, only differences among seedbed preparations and grasses are presented. A Duncan's new multiple range test was used to separate means (Steel and Torrie 1960).

\section{Results}

\section{Drill Seeding}

Summer thunderstorm activity began prior to mechanical seedbed preparation and planting at SRER in 1981. Soil moisture observations while disk plowing indicated penetration to $30-\mathrm{cm}$ depths; however, the surface $10 \mathrm{~cm}$ was dry when seeds were drilled on 15 and 16 July. A 10 -minute storm deposited $20 \mathrm{~mm}$ during 17 July. After the storm, runoff was observed exiting control and chemically prepared seedbeds, but not mechanically prepared seedbeds. We observed 'Cochise' and 'Catalina' lovegrasses, Kleingrass, and sideoats grama seedlings during late July on mechanically prepared seedbeds, while no seedlings were observed on control and chemically prepared seedbeds.

Some 'Cochise', 'Catalina', and 'A-84' lovegrasses, Kleingrass, and sideoats grama seedlings which germinated in July 1981 were present on the mechanically prepared seedbeds in fall 1981 (Tables 2 and 3), although late July and August were dry (Fig. 2). All grasses were present on all seedbed preparations in fall 1983 and 1984. Grass seedling emergence in herbicidal treatments in fall 1982 indicated that seed sown in soil might have remained viable for more than one growing season. Seedlings might have survived because the herbicide had leached from the upper soil profile (Baur 1979, Ibarra-F. 1984) and shrub competition for water and nutrients decreased (Mutz and Scifres 1975).

Immediately after mechanical seedbed preparation and planting in 1982 the summer rainy season began. Storms occurred at 3- to 5-day intervals with $209 \mathrm{~mm}$ recorded by 15 August. By 20 July seedlings of all species were observed in mechanical, chemical, and control seedbeds.

Initially sideoats grama densities were greatest in the 1981 plantings, while 'Cochise'lovegrass and buffelgrass densities were great-

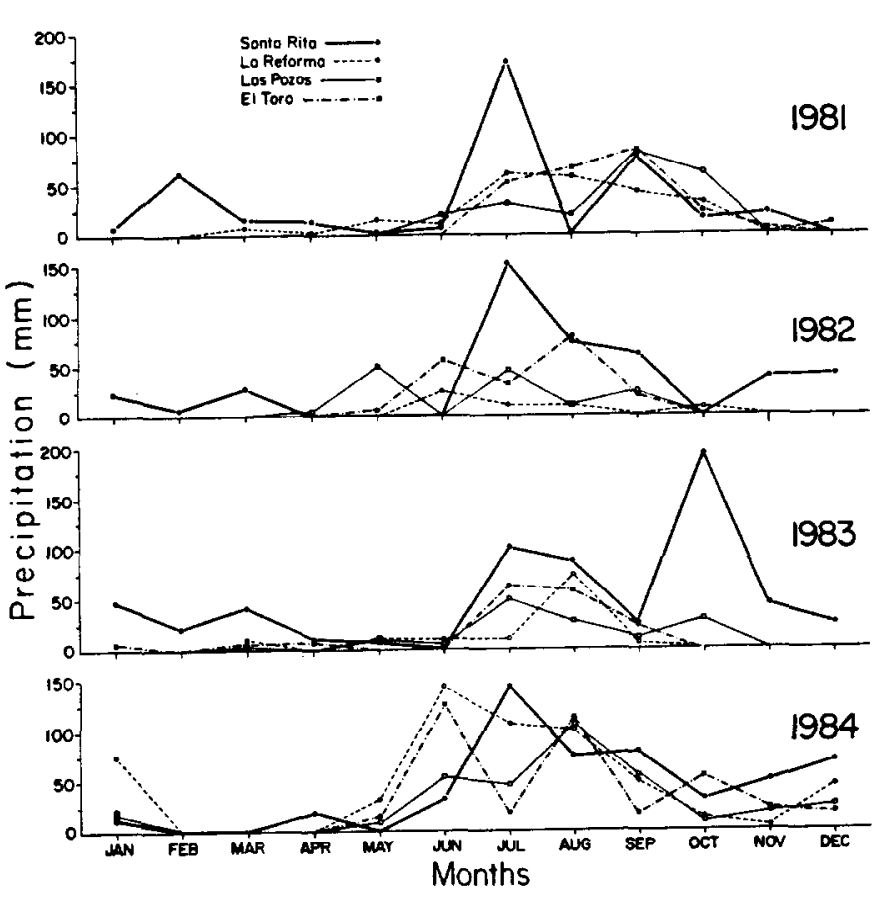

Fig. 2. Monthly amounts of precipitation ( $\mathrm{mm}$ ) from 1981 to 1984 at Santa Rita Experimental Range (SRER), Arizona, U.S.A., La Reforma, Los Pozos and El Toro, Chihuahua, Mexico.

est in the 1982 plantings (Table 2). However, by $1984^{~ ' C o c h i s e ' ~ a n d ~}$ 'Catalina' lovegrass densities were greater $(\alpha=0.05)$ than the other grasses in both the 1981 and 1982 plantings. Increases in 'Cochise' and 'Catalina' lovegrass densities between 1983 and 1984 are attributed to seed germination at cooler temperatures, fall precipitation, and chemical seedbed preparation.

Seeds of grasses sown in the field were germinated under simulated summer, fall, winter and spring soil temperature regimes. 'Cochise' and 'Catalina' lovegrass seeds germinated in summer, fall and spring regimes (Martin-R. and Cox 1984) while the remaining 
Table 5. Mean density and forage production of 6 or 7 grasses on 3 mechanical seedbed preparations following hand broadcast seeding in summer 1981 and 3 sites in Chihuahua, Mexico.

\begin{tabular}{|c|c|c|c|c|}
\hline Site & $\begin{array}{c}\text { Year } \\
\text { Evaluated' }\end{array}$ & $\begin{array}{c}\text { Two-way } \\
\text { Railing }\end{array}$ & $\begin{array}{c}\text { Disk } \\
\text { Plowing }\end{array}$ & $\begin{array}{c}\text { Disk plowing } \\
\text { Plus contour } \\
\text { furrowing }\end{array}$ \\
\hline \multirow{5}{*}{ La Reforma } & & \multicolumn{3}{|c|}{-Density (Plants $/ \mathrm{m}^{2}$ ) } \\
\hline & 1981 & $16^{\mathrm{a}}$ & $17^{*}$ & $15^{\mathrm{a}}$ \\
\hline & 1982 & $1^{b}$ & $5^{\mathrm{a}}$ & $5^{a}$ \\
\hline & 1983 & $0^{b}$ & $1^{a}$ & $1^{a}$ \\
\hline & 1984 & $0^{b}$ & $1^{n}$ & $1^{\mathbf{a}}$ \\
\hline \multirow[t]{4}{*}{ Los Pozos } & $1981^{2}$ & $2^{b}$ & $8^{n}$ & $6^{a}$ \\
\hline & $1982^{2}$ & $3^{b}$ & $6^{\mathrm{a}}$ & $7^{\mathrm{a}}$ \\
\hline & $1983^{2}$ & $\mathbf{l}^{\mathrm{b}}$ & $3^{*}$ & $3^{\mathrm{a}}$ \\
\hline & $1984^{2}$ & $0^{\text {b }}$ & $1^{*}$ & $1^{a}$ \\
\hline \multirow[t]{4}{*}{ El Toro } & 1981 & $16^{b}$ & $33^{a}$ & $29^{a}$ \\
\hline & 1982 & $6^{\mathrm{b}}$ & $18^{a}$ & $16^{\mathrm{a}}$ \\
\hline & 1983 & $2^{b}$ & $11^{\mathrm{a}}$ & $12^{\mathrm{a}}$ \\
\hline & 1984 & $0^{b}$ & $6^{a}$ & $8^{a}$ \\
\hline \multirow{2}{*}{ La Reforma } & 1983 & \multicolumn{3}{|c|}{-Forage Production $\left(\mathrm{g} / \mathrm{m}^{2}\right)$} \\
\hline & 1984 & $0^{b}$ & $6^{\mathrm{a}}$ & $15^{\mathrm{a}}$ \\
\hline \multirow[t]{2}{*}{ Los Pozos } & $1983^{2}$ & $3^{b}$ & $17^{a}$ & $29^{a}$ \\
\hline & $1984^{2}$ & $0^{b}$ & $14^{a}$ & $14^{2}$ \\
\hline \multirow[t]{2}{*}{ El Toro } & 1983 & $4^{b}$ & $38^{a}$ & $38^{2}$ \\
\hline & 1984 & $0^{b}$ & $52^{a}$ & $52^{a}$ \\
\hline
\end{tabular}

'Means in rows followed by the same letter are not significantly different $(\alpha=0.05)$ by Duncan's multiple range test.

${ }^{2}$ Grazed by cattle.

grasses germinated only in summer regimes (USDA-ARS, unpublished data).

In fall 1983, $188 \mathrm{~mm}$ of precipitation was recorded at SRER between 3 and 7 October, 10 days after the 1983 sampling was completed. By 20 October new 'Cochise' and 'Catalina' lovegrass seedlings began to emerge in the 1981 and 1982 plantings on chemically treated areas (Tables 2 and 3). Of the 'Catalina' lovegrass seedlings observed all appeared in the original drill furrows, while $50 \%$ of the 'Cochise' lovegrass seedlings appeared in the drill furrows and $50 \%$ appeared in undisturbed areas under the canopies of dead creosotebush plants. 'Cochise' and 'Catalina' lovegrass seed germination and seedling emergence in fall 1983 suggests: (1) seeds of both species are remaining viable in soil for 1 or 2 years, (2) 'Cochise' lovegrass seeds from existing mature plants are colonizing new areas, and (3) a competitive relationship between creosotebush and perennial grasses for water and nutrients does exist (Mutz and Scifres 1975).
'Cochise' and Catalina' lovegrasses and buffelgrass (planted in 1982) forage production was generally greater than that of the other species in 1983 on the 1981 and 1982 plantings (Table 2). By 1984, however, 'Cochise'lovegrass forage production was superior $(\alpha=0.05)$ to that of all other grasses. In 1983 more forage was produced on 2-way railed and plowed seedbeds in the 1981 and 1982 plantings (Table 3). Following the establishment of additional 'Cochise' and 'Catlina' lovegrass plants in chemically prepared seedbeds, in fall 1983 forage production in plowed, railed, and chemically ( 1.0 and $1.5 \mathrm{~kg} / \mathrm{ha}$ ) prepared seedbeds was similar $(\alpha=0.05)$. In imprinted seedbeds the density and forage production of seeded species was generally less than in plowed and chemically ( 1.0 and $1.5 \mathrm{~kg} / \mathrm{ha}$ ) prepared seedbeds. Initial stand densities were influenced by soil sluffing which covered newly emerging seedlings in the furrow pit.

At the 3 Mexican sites seeded species were not present on mechanical and chemical seedbeds drill seeded in 1982. Failures were due to below-normal summer rainfall in 1982 and 1983 (Fig. 2) and ants, which we observed harvesting seeds from drill rows.

\section{Hand Broadcast Seeding}

Total annual precipitation in 1981 was $42 \%$ below the long-term average of $400 \mathrm{~mm}$ at La Reforma, $18 \%$ below the average of 253 $\mathrm{mm}$ at Los Pozos, and $18 \%$ below the average of $270 \mathrm{~mm}$ at El Toro (Martin-R. 1984, Fig. 2). Nevertheless, seedlings of most species were present on the 3 mechanically prepared seedbeds in fall 1981 (Table 4). Seedlings emerged following early summer rains at El Toro, but following late summer and early fall rains at La Reforma and Los Pozos. Densities were similar on the 3 mechanically prepared seedbeds at La Reforma in 1981, but were greater on plowed than on 2-way railed seedbeds at Los Pozos and El Toro (Table 5).

Total annual precipitation was 87,47 , and $29 \%$ below normal in 1982 at La Reforma, Los Pozos, and El Toro, respectively, while 130\% above normal at SRER (Martin-R. 1984, Fig. 2). Seedlings failed to survive at La Reforma and Los Pozos.

Immediately after planting at El Toro in 1982 the summer rains began, but they were followed by 50 consecutive dry days in July and August. Thunderstorm activity resumed in early September. Seedlings of all species were present in fall 1982 on the 1982 plantings (Table 6), but heights varied from 1 to $3 \mathrm{~cm}$. We suspect seedlings emerged from seed that germinated in September. More seedlings were present in plowed seedbeds than in 2-way railed and imprinted seedbeds (Table 7).

Grasses that emerged in either late August or September at La Reforma and Los Pozos in 1981, and El Toro in 1982, were small and leaves were yellow in 1982 . The majority of these plants died between 1982 and 1984 . When rainfall conditions improved in

Table 6. Density and forage production of range grasses averaged over 4 mechanical seedbed preparations following hand broadcast seeding in summer 1982 at El Toro, Chihuahua, Mexico and Santa Rita Experimental Range (SRER), Arizona, U.S.A.

\begin{tabular}{|c|c|c|c|c|c|c|c|c|}
\hline & & \multicolumn{7}{|c|}{ Grass } \\
\hline \multicolumn{2}{|c|}{ Year } & \multicolumn{4}{|c|}{ Lovegrasses } & \multirow[b]{2}{*}{ Kleingrass } & \multirow[b]{2}{*}{ Sideoats grama } & \multirow[b]{2}{*}{ Buffelgrass } \\
\hline Site & Evaluated & $A-68$ & Cochise & A-84 & Catalina & & & \\
\hline El Toro & $\begin{array}{l}1982 \\
19832 \\
1984 \\
1982 \\
1983 \\
1984\end{array}$ & $\begin{array}{c}1^{\mathrm{b}} \\
0^{\mathrm{b}} \\
0^{\mathrm{b}} \\
11^{\mathrm{c}} \\
5^{\mathrm{cd}} \\
1^{\mathrm{b}}\end{array}$ & $\begin{array}{c}10^{\mathrm{a}} \\
1^{\mathrm{a}} \\
1^{\mathrm{a}} \\
32^{\mathrm{ab}} \\
21^{\mathrm{a}} \\
12^{\mathrm{a}}\end{array}$ & $\begin{array}{c}1^{\mathrm{b}} \\
0^{\mathrm{b}} \\
0^{\mathrm{b}} \\
32^{\mathrm{ab}} \\
14^{\mathrm{b}} \\
14^{\mathrm{a}}\end{array}$ & $\begin{array}{c}\text { ensity (Pl } \\
5^{\mathrm{ab}} \\
1^{\mathrm{a}} \\
0^{\mathrm{b}} \\
32^{\mathrm{ab}} \\
14^{\mathrm{b}} \\
10^{\mathrm{a}}\end{array}$ & $\begin{array}{c}6^{\mathrm{ab}} \\
1^{\mathrm{a}} \\
1^{\mathrm{a}} \\
39^{\mathrm{a}} \\
4^{\mathrm{d}} \\
1^{\mathrm{b}}\end{array}$ & $\begin{array}{r}2^{b} \\
1^{a} \\
1^{a} \\
29^{b} \\
9^{c} \\
3^{b}\end{array}$ & $\begin{array}{r}10^{\mathrm{a}} \\
1^{\mathrm{a}} \\
1^{\mathrm{a}} \\
38^{\mathrm{a}} \\
19^{\mathrm{c}} \\
10^{\mathrm{a}}\end{array}$ \\
\hline $\begin{array}{l}\text { El Toro } \\
\text { SRER }\end{array}$ & $\begin{array}{c}19832 \\
1984 \\
1983 \\
1984\end{array}$ & $\begin{array}{c}0^{c} \\
0^{c} \\
50^{b c} \\
95^{b}\end{array}$ & $\begin{array}{r}15^{a} \\
31^{a} \\
108^{a} \\
189^{a}\end{array}$ & $\begin{array}{r}0^{c} \\
0^{c} \\
29^{c} \\
104^{b}\end{array}$ & $\begin{array}{c}\text { age Prod } \\
2^{b} \\
0^{c} \\
63^{b} \\
120^{b}\end{array}$ & $\begin{array}{c}\left(\mathrm{g} / \mathrm{m}^{2}\right) \\
4^{\mathrm{b}} \\
36^{\mathrm{a}} \\
21^{\mathrm{c}} \\
47^{\mathrm{bc}}\end{array}$ & $\begin{array}{r}4^{\mathrm{b}} \\
6^{\mathrm{b}} \\
37^{\mathrm{c}} \\
118^{\mathrm{b}}\end{array}$ & $\begin{array}{c}9^{a b} \\
7^{b} \\
124^{a} \\
151^{a}\end{array}$ \\
\hline
\end{tabular}

'Means in rows followed by the same letter are not significantly different $(\alpha=0.05)$ by Duncan's multiple range test. 
Table 7. Mean density and forage production of 7 range grasses on 4 mechanical seedbed preparations following hand broadcast seeding in summer 1982 at El Toro, Chihuahua, Mexico and Santa Rita Experimental Range (SRER), Arizona, U.S.A.

\begin{tabular}{|c|c|c|c|c|c|}
\hline Site & $\begin{array}{c}\text { Year } \\
\text { evaluated } 1\end{array}$ & $\begin{array}{l}\text { Two-way } \\
\text { railing }\end{array}$ & $\begin{array}{c}\text { Disk } \\
\text { plowing }\end{array}$ & $\begin{array}{l}\text { Disk plowing plus } \\
\text { contour furrowing }\end{array}$ & $\begin{array}{c}\text { Land } \\
\text { imprinting }\end{array}$ \\
\hline & & & -Dens & ty (Plants $/ \mathrm{m}^{2}$ ) & \\
\hline \multirow{3}{*}{ El Toro } & 1982 & $4^{b}$ & $7^{\mathrm{a}}$ & $7^{a}$ & $1^{\mathrm{b}}$ \\
\hline & $1983^{2}$ & $0^{b}$ & $1^{a}$ & $1^{a}$ & $0^{\mathrm{b}}$ \\
\hline & 1984 & $0^{b}$ & $1^{a}$ & $1^{\mathrm{a}}$ & $0^{\mathrm{b}}$ \\
\hline \multirow[t]{3}{*}{ SRER } & 1982 & $28^{b}$ & $41^{\mathrm{a}}$ & $45^{\mathrm{a}}$ & $8^{c}$ \\
\hline & 1983 & $16^{a}$ & $11^{\circ}$ & $13^{a}$ & $3^{b}$ \\
\hline & 1984 & $7^{b}$ & $6^{b}$ & $13^{*}$ & $2^{b}$ \\
\hline \multirow{2}{*}{ El Toro } & & & -Forag & Production $\left(\mathrm{g} / \mathrm{m}^{2}\right)$ & \\
\hline & $\begin{array}{l}1983^{2} \\
1984\end{array}$ & $0^{b}$ & $\begin{array}{r}8 \\
10^{a}\end{array}$ & $118^{\mathrm{a}}$ & $\begin{array}{l}0^{\circ} \\
0^{b}\end{array}$ \\
\hline \multirow[t]{2}{*}{ SRER } & 1983 & $34^{b}$ & $89^{\mathrm{a}}$ & $117^{*}$ & $7^{\circ}$ \\
\hline & 1984 & $115^{\mathrm{ab}}$ & $128^{\circ}$ & $159^{\mathrm{a}}$ & $68^{b}$ \\
\hline
\end{tabular}

'Means in rows followed by the same letters are not significantly different $(\alpha=0.05)$ by Duncan's multiple range test.

${ }^{2}$ Grazed by cattle.

Mexico during 1984 (Fig. 2) the survivors produced minor quantities of forage (Tables 4 and 6). Seedlings in 2-way railed and imprinted seedbeds eventually died, while a portion of the seedlings in plowed seedbeds survived (Tables 5 and 7).

Seedlings of all species hand seeded in summer 1982 at SRER were greatest in plowed, intermediate in 2-way railed, and least in imprinted seedbeds (Tables 6 and 7). With the exception of 'A-68' lovegrass, all species densities exceeded 28 plants $/ \mathrm{m}^{2}$. By 1984 'Cochise', 'A-84', and 'Catalina' lovegrasses and buffelgrass densities exceeded 9 plants $/ \mathrm{m}^{2}$ while 'A-68' lovegrass, Kleingrass, and sideoats grama densities were less than 4 plants $/ \mathrm{m}^{2}$.

\section{Comparisons of Drill and Hand Broadcast Seedings}

Mean grass densities resulting from drilling at SRER in 1981 and 1982 were 1.2 and 6.0 plants $/ \mathrm{m}^{2}$ after the initial growing seasons on the 1981 and 1982 plantings, respectively (Table 2). Densities increased in the 1981 plantings, decreased in the 1982 plantings, but were about the same $\left(2.7\right.$ and 2.3 plants $\left./ \mathrm{m}^{2}\right)$ on both plantings by fall 1984. Mean seedling densities at SRER on the 1982 hand broadcast areas were 5.0 and 3.2 times greater than on drill seeded areas in 1982 and 1984, respectively (Tables 2 and 6). Mean forage production on the drill seeded areas was 2.7 and 1.5 times greater than on the hand broadcast area in 1983 and 1984 , respectively. Mean densities after hand broadcast seeding in Mexico varied from 5.3 to 25.8 plants $/ \mathrm{m}^{2}$ after the initial growing season in 1981 , but varied from 0.5 to 3.5 plants $/ \mathrm{m}^{2}$ in 1984 (Table 4).

When 2 dry summers followed in sequence, grass seedlings were not present in drilled or hand broadcast seeded areas, such as at La Reforma and Los Pozos on the 1982 plantings. At El Toro grass seedlings were not present in drill seeded areas but were present in hand broadcast areas in 1982.

The density and forage production of grasses sown with the drill, at SRER in 1981 and 1982, were initially greater on plowed and railed seedbeds than on chemical, imprinted and control seedbeds (Table 3). By fall 1984, density and forage production were either greater on the 1.0 and $1.5 \mathrm{~kg} /$ ha chemically treated seedbeds or similar on chemically and mechanically prepared seedbeds. Plants from hand broadcast and drilled seed on plowed seedbeds persisted and produced more forage than plants on railed and imprinted seedbeds (Table $3,5,7$ ).

\section{Discussion}

The amount and distribution of summer rainfall needed to initially establish perennial grasses on semiarid southwestern
U.S.A. and northern Mexico rangelands occurs in 1 of 10 summers (Cox and Jordan 1983). By utilizing drought tolerant plant materials such as 'Cochise' and 'Catalina' lovegrasses, and mechanical and chemical seedbed preparations which dramatically reduce creosotebush competition (Ibarra-F. 1984), we were able to initially establish perennial grasses in 6 of our 8 attempts. Unfortunately, initial establishment does not appear to be related to persistence and grasses initially established in late summer following a dry early summer usually die in following years.

It is important to note that total summer precipitation at SRER was $1.3,1.3$, and 1.6 times greater than the long-term average in 1982, 1983 and 1984, respectively (Green and Martin 1967). The probability of this pattern continuing for another summer, or this cycle repeating within the next 50 to 60 years is remote (Sellers and Hill 1974, Osborn 1983).

Two-way railing and land imprinting disturb the soil surface; however, neither treatment effectively reduces creosotebush competition (Ibarra-F. 1984) and initially established perennial grasses die within 3 or 4 years. Disk plowing significantly reduces creosotebush competition but it also eliminates native perennial grasses found under or near the creosotebush. If plowing and seeding are conducted prior to a summer, plowing kills existing native perennial grasses; and seeded species if initially established can not be expected to produce abundant forage, even when rainfall conditions improve.

Available nitrogen, which is typically low in semidesert soils (Skujins 1981), is concentrated under creosotebush canopies (CoX et al. 1984a). Mechanical seedbed treatments tend to mix surface soils and redistribute nitrogen over the treated area. If nitrogen under creosotebush is adequate for perennial grass seedling growth, but concentrations between plants are inadequate, then soil mixing could result in a seedbed where the average nitrogen concentration is less than ideal for initial seedling growth (Cox et al. 1984b). In summers with above-average rainfall the dilution of nitrogen may not be important because seedling roots expand and occupy a greater soil volume. However, when seedling growth is limited by water, the redistribution of nitrogen may have a dramatic effect on seedling growth and future survival.

Tebuthiuron at 1.0 and $1.5 \mathrm{~kg} /$ ha rates effectively reduced creosotebush competition (Ibarra-F. 1984), and seeded grasses emerged and persisted when summer rainfall was above average. As creosotebush competition declined, both seeded species and native perennial grasses dominated the treated area. Establishment of 'Cochise' and 'Catalina' lovegrasses with the native grasses resulted in a diverse grassland community. The higher herbicide rates did not appear to damage the native perennial grass when applied prior to the occurrence of a summer with below-average rainfall and native grasses dominated the site in 2 to 3 years even when the seeded species were not established.

Ranchers and researchers have over-estimated the grazing capacity of seeded areas and have not correctly managed such areas after perennial grasses were established (Cox et al. 1982). Ranchers who wish to seed perennial grasses on disk plowed or chemical seedbeds should answer the following questions: (1) Will $I$ fence the seeded area and manage it separately from untreated portions of the same pasture? (2) Can I afford to completely rest the seeded area for 2 or more years? and (3) Will I set stocking rates based on the perennial forage produced in the driest summer? If one or more of these questions is answered negatively, the seeded treatment will likely fail because of management, even if initially successful. If a failure occurs, the rancher can expect reinvasion by shrubs, accelerated erosion, and a direct dollar loss.

\section{Literature Cited}

Anderson, D., L.P. Hamilton, H.G. Reynolds, and R.R. Humphrey. 1957. Reseeding desert grassland ranges in southern Arizona. Arizona Agr. Exp. Sta. Bull. 249. 
Baur, J.R. 1979. Establishing kleingrass and bermudagrass pastures using glyphosate and tebuthiuron. J. Range Manage. 32:119-122.

Baur, J.R., R.W. Bovey, and E.C. Holt. 1977. Effect of herbicide on production and protein levels in pasture grasses. Agron. J. 69:846-851.

Buffington, L.C., and C.H. Herbel. 1965. Vegetation changes on a semidesert grassland range. Ecological Monogr. 35:139-164.

Campbell, J.B., and J.T. Cassudy. 1949. Determining forage weight on southern forest ranges. J. Range Manage. 2:30-32.

COTECOCA., 1978. Coeficientes de Agostadero de la Republica Mexicana. Estato de Chihuahua. Secretaria de Agricultura y Ganaderia Mexico, D.F. [In Spanish].

Cox, J.R., H.L. Morton, T.N. Johnsen, Jr., G.L. Jordan, S.C. Martin, and L.C. Fierro. 1982. Vegetation restoration in the Chihuahuan and Sonoran Deserts of North America. USDA-Agr. Res. Serv. ARM-W-28.

Cox, J.R., and G.L. Jordan. 1983. Density and production of seeded range grasses in southeastern Arizona. J. Range Manage. 36:649-652.

Cox, J.R., H.A. Schreiber, and H.L. Morton. 1984a. The initial growth of two range grasses from nonfertilized and fertilized soils collected from creosotebush communities in the southwestern United States. J. Range Manage. 36:726-729.

Cox, J.R., J.M. Parker, and J.L. Stroehlein. 1984b. Soil properties in creosotebush communities and their relative effects on the growth of seeded range grasses. Soil Sci. Soc. Amer. J. 48:1442-1445.

Dixon, R.M., and R. Simanton. 1980. Land imprinting for better water management. Symposium on watershed management. Vol. II. Amer. Soc. Civil Eng. p. 809-825. Boise, Idaho.

Federer, W.T. 1967. Experimental design, theory and application. Oxford \& IBS Publishing Co. New Delhi, India.

Green, C.R., and S.C. Martin. 1967. An evaluation of precipitation, vegetation and related factors on the Santa Rita Experimental Range. Univ. Arizona, Institute of Atmospheric Physics. Tech. Rep. on Metorology and Climatology of Arid Regions. No. 17.

Hastings, J.R., and R.M. Turner. 1965. The changing mile. Univ. Arizona Press, Tucson.

RANGE ECONOMICS John P. Workman, Utah State University A new title in the Biological Resource Management Series

"A concise, well-written introduction to the science of range economics. The author's extensive use of range management examples puts new life into the frequently dry and often misunderstood concepts of basic production economics and financial analysis....the book provides a very readable and useful addition to the range and natural resource management literature."-J of Range Management

CONTENTS: An Overview of Range Economics. Economics in a Range Management Setting. Supply and Demand-The Basic Tools. The Production Function. Optimum Intensity of Production. Optimum Combination of Inputs. Optimum Combination of Outputs-The Economics of Multiple Use. Discounting-Adjusting Costs and Returns for the Effects of Time. Economic Analysis of Private Range Improvements. Benefit-Cost Analysis on Public Lands. Index.

$1986 \cdot 240$ pages - ISBN: $0-02-948810-9 \cdot \$ 34.50$

To place a VISA or MasterCard order, call toll-free 1-800-257-5755

(In NJ, AK, or HI dial direct 1-609-257-5755) or order from

\section{Macmillan Publishing Company}

866 Third Ave., New York, N.Y. 10022 Att: D. J. Decker

For more information on this series write to above address. Prices are good in U.S. only and are subject to chenge without notice.
Huss, L.D., and E.L. Aguirre. 1974. Fundamentos de manejo de pastizales. Departamento de Zootecnia. Instituto Tecnologico y de Estatios Superiores de Monterrey. Monterrey, N.L. [In Spanish].

Humphrey, R.R. 1958. The desert grassland; a history of vegetational changes and an analysis of causes. Bot. Rev. 24:193-252.

Ibarra-F., F.A. 1984. Brush control, forage production and tebuthiuron residues in soils and plants at four creosotebush (Larrea tridentata) sites in the Chihuahuan and Sonoran Deserts. M.S. Thesis, Univ. Arizona, Tucson.

Jacoby, P.W., D.N. Ueckert, and F.S. Hartman. 1982. Control of creosotebush (Larrea tridentata) with pelleted tebuthiuron. Weed Sci. 30:307-310.

Jordan, G.L. 1981. Range reseeding and brush management. Ariz. Agr. Exp. Sta. Bull. No. T81121

Martin-R., M.H., and J.R. Cox. 1984. Germination profiles of introduced lovegrasses at six constant temperatures. J. Range Manage. 37:507-509.

Martin-R., M.H. 1984. Establishment of range grasses on various seedbeds at four Larrea tridentata sites in Chihuahua, Mexico and Arizona, U.S.A., M.S. Thesis, Univ. Arizona, Tucson.

Mutz, J.L., and C.J. Scifres. 1975. Influence of soil texture and planting depth on buffelgrass emergence. Rangeland Resources Research 1971-1974. Texas Agr. Exp. Sta., Texas A\&M, College Station.

Osborn, H.B. 1983. Precipitation characteristics affecting hydrologic responses of southwestern rangeland. USDA - Agr. Res. Serv. ARM-W-34.

Pechanec, J.F., and G.F. Pickford. 1937. A weight estimate method for determination of range or pasture production. J. Amer. Soc. Agron. 29:894-904.

Sellers, W.D., and R.H. Hill. 1974. Arizona climate (1931-1972). Univ. Arizona Press, Tucson.

Skujins, J.J. 1981. Nitrogen cycling in arid ecosystems. In: F.E. Clark and T. Rosswell (ed.), Terrestrial nitrogen cycles. Ecol. Bull. (Stockholm) 33:477-491.

Soll Survey Staff. 1975. Soil taxonomy: A basic system of soil classification for making and interpreting soil surveys. USDA-SCS Agr. Handb. 436. U.S. Government Printing Office, Washington, DC.

Steel, R.G.D, and J.H. Torrie. 1960. Principles and procedures of statistics. McGraw Hill. New York.

\section{CALL FOR ABSTRACTS GRAZING LIVESTOCK NUTRITION CONFERENCE July 23-24, 1987 Jackson Wyoming}

Abstracts will be presented as poster sessions and will compliment invited papers in the areas of:

Factors Influencing Energy Requirements of Livestock Techniques for Estimating Nutrient Intake and Utilization Factors Influencing Digesta Flow Supplementation Practices

Abstract and program information can be obtained from:

$$
\begin{gathered}
\text { Grazing Livestock Nutrition Conference } \\
\text { Department of Animal Science } \\
\text { University of Wyoming } \\
\text { Laramie, WY } 82071
\end{gathered}
$$

